\title{
Corporate social responsibility practice of Malaysian public listed government-linked compa- nies: A dimensional analysis
}

\author{
Lim Boon Keong ${ }^{a *}$, Suresh Ramakrishnan ${ }^{b}$ and Sanil S. Hishanc
}

${ }^{a}$ Faculty of Business and Management, Southern University College, Malaysia a,b,c Faculty of Management, Universiti Teknologi Malaysia, Malaysia

CH R O N I C L E

Article history:

Received: November 26, 2017

Received in revised format:

March 31, 2018

Accepted: April 4, 2018

Available online:

April 5, 2018

Keywords:

Corporate social responsibility

CSR practice

CSR ratings

CSR dimensions

Public listed companies

Government-linked companies

CSRHub

\section{Introduction}

A government-linked company (GLC) is a private or public commercial company in which an existing government owns a direct controlling stake of $50 \%$ or has a government as a shareholder (Siwar \& Harizan, 2009). In Malaysia, government-linked companies (GLCs) and government-linked investment companies (GLICs) play a significant role in making up the backbone of national economic structure and growth (Mariati \& Kamarulzaman, 2005). With a mix of social and commercial objectives, they serve a central and major role in providing important public utilities and services such as energy, financial services, telecommunications, transportation, etc. (Atan \& Razali, 2013). GLCs are given special advantages in terms of access to funds, tenders, and opportunities and therefore, subject to a greater requirement to comply with the government policies, including additional social obligations, i.e. corporate social responsibility (CSR). They are mandated to share the government responsibility in fulfilling their public accountability by leading other public listed companies (PLCs) to have good corporate practices on social and environmental matters (Hawani et al., 2011; Gandhi et al., 2018).

* Corresponding author.

E-mail address: dericlimbk@gmail.com (L. B. Keong)

(C) 2018 by the authors; licensee Growing Science, Canada doi: $10.5267 / \mathrm{j} . \mathrm{msl} .2018 .4 .005$ 
In GLCs, government-appointed board of director members and senior management make major decisions regarding contract awards, strategy, restructuring, financing, merger, acquisition and divestment for GLCs either directly or through GLICs. The GLICs controlled GLCs by allocation of funds for their investment (Bhatt, 2016). There are seven GLICs, namely, Employees Provident Fund, Khazanah National Bhd, Kumpulan Wang Amanah Pencen, Lembaga Tabung Angkatan Tentera, Lembaga Tabung Haji, Menteri Kewangan Diperbadankan and Permodalan Nasional Bhd. Ministry of Finance and GLICs are investment arms of the government that allocated funds to GLCs (Putrajaya Committee on GLC High Performance Transformation, 2013).

In 2006, CSR development in Malaysia made a big leap when the Prime Minister (PM) who was also the Finance Minister in Budget Speech 2007/08 highlighted the requirements for PLCs to report on their CSR activities to indoctrinate a socially responsible culture. Effective communicating and reporting will help Malaysian companies, including the GLCs, to gain public confidence and recognition, help attract the interest of socially responsible investment funds and more effectively manage different stakeholder expectations other than deliver financial and operational results (Shirley et al., 2009, Ramakrishnan et al. 2016). This was supported through the launch of The Silver Book by Putrajaya Committee on GLC (PCG) which provides the guidelines of CSR reporting to GLCs and the launch of CSR framework for PLCs to make CSR reporting by Bursa Malaysia (BM) in 2006. These timely initiatives are useful in positioning Malaysian companies in the globally competitive market using the CSR platform.

The CSR framework and the Silver Book for the PLCs and GLCs are to help them in the practice of CSR. However, they neither provide the complete story about CSR nor the answer. The guidelines provided are not applicable uniformly to all sectors and companies as each has to align them with the nature and purpose of business. The framework proposes four dimensions:

- Environment: Biodiversity, Climate Change, Endangered Wildlife, Energy (Renewable Energy, Energy Efficiency, Biofuel) and Waste Management;

- Community: Children, Education (Schools Adoption Scheme), Employee Volunteerism, Graduate Employment, Underprivileged and Youth Development;

- Marketplace: Corporate Governance, Green Products, Ethical Procurement, Social Branding, Stakeholder Engagement, Supplier Management and Vendor Development; and

- Workplace: Employee Involvement, Gender Issues, Human Capital Development, Health \& Safety, Human Rights, Labour Rights, Quality of Life and Workplace Diversity.

In Malaysia, there is an absence of internationally adopted accounting standards for disclosing CSR information. Therefore, CSR disclosures in Malaysia would be solely voluntary in nature and companies have full discretion in deciding what to disclose in annual reports. The lack of the international CSR reporting standards such as GRI and KLD in Malaysia makes the research on the CSR practice of Malaysian companies become limited. Very few studies were conducted specifically on GLCs' CSR practice through a dimensional analysis. None of the past literature applied CSR rating to proxy for CSR practice in Malaysia.

The aim of this paper is to conduct a dimensional analysis on the CSR practice of public-listed GLCs through the adoption of an international CSR rating developed by CSRHub. There are four dimensions defined by CSRHub, namely community, employees, environment and governance. Each dimension is further divided into three subcategories to study the specific regime of each CSR dimension. Three research objectives are outlined:

(1) To identify the CSR dimension that GLCs performed the best (with the highest average CSR rating). 
(2) To identify the dimensional subcategory that GLCs performed the best (with the highest average CSR rating).

(3) To examine GLCs from which sector/industry has the best CSR practice (with the highest average CSR rating).

\section{Literature review}

The study accomplished by Teoh and Thong (1984) is one of the earliest and major studies on CSR practice conducted in Malaysian context. The study surveyed a combination of one hundred foreign and locally owned companies in Malaysia through a personal interview questionnaire on three CSRrelated issues: the concept of CSR, the nature and extent of corporate involvement in such activities and the corporate social reporting. The results show that only 29 percent of the companies in the sample reported on CSR practice in their annual report, in which the most frequently reported CSR dimensions were human resource and products or services related issues. However, the study did not examine the level of CSR practice and the extent of CSR disclosures. The results also show that foreign-owned companies made more CSR disclosures than local Malaysian companies did.

Andrew (1989) studied 119 annual reports of public-listed companies in Malaysia and Singapore in 1983 through examining their level of CSR disclosures found a disappointing result as only $26 \%$ of the companies engaged in CSR practice (Alamer et al., 2015a; 2015b). Large- and medium-sized companies were inclined to engage more in CSR practice as compared to smaller-sized companies. The most frequently reported CSR dimension or theme was human resource related activities. Companies from banking and finance industry in the sample exhibited higher CSR disclosures in the annual reports. However, the study did not make any comparison between Malaysian and Singaporean companies in relation to CSR practice. Therefore, the CSR practice in each individual nation remained unidentified.

Ahmad et al. (2003) examined 98 listed companies across different industries from the main board of Kuala Lumpur Stock Exchange (KLSE) through content analysis on their annual reports. The results showed that $84 \%$ of the companies engaged in CSR practice and made certain level of CSR disclosure. Four dimensions of CSR (environment, community, marketplace and workplace) were studied and found that $72.4 \%$ of the companies made disclosure on marketplace dimension in terms of products and services subcategory, whilst $62.2 \%$ of the companies made disclosure on workplace dimension in terms of employee subcategory. Companies from banking and finance industry also reported the highest level of CSR disclosure as compared to other industries. Comparatively, Shirley et al. (2009) examined the CSR web reporting made by 117 second board companies listed on Bursa Malaysia through content analysis on their annual reports in 2006. Only $23.1 \%$ of the companies engaged in CSR practice and made certain level of CSR disclosure. Out of the four dimensions, community dimension topped the list followed by environment dimension, contrarily, marketplace is the least favorable one. Companies from industrial products industry made the highest proportion of CSR disclosure. Hawani et al. (2011) assessed the level of CSR disclosure of 44 GLCs listed on Bursa Malaysia by developing disclosure index based on four general themes (human resource, marketplace, community and environment) of CSR through content analysis found that there was a shift from human resource to marketplace from 2005 to 2006. Based on the analysis of marketplace dimension, GLCs showed more concern on the subcategories of product quality and safety, research and design, shareholder communication channel and customer service. The least favored dimension was environment.

\section{Methodology}

Based on the market capitalization as at the end of 2016, out of the top 100 PLCs on Bursa Malaysia, 37 were identified to be GLCs. 7 GLCs were excluded from the present study due to the unavailability of data on CSRHub (CSR rating database). Therefore, a total of 30 GLCs were included (Appendix 1). 
CSRHub is the world's largest sustainability business intelligence database which provides remarkably comprehensive and relevant CSR or Environmental, Social and Governance (ESG) information. The database provides transparent ratings and rankings of 17,267 companies from 133 countries, driven by 525 industry-leading CSR/ESG data sources (https://www.csrhub.com/).

CSRHub measures the CSR performance of companies based on four categories/dimensions, namely community, employees, environment and governance. Each dimension is further divided into three main subcategories:

- Community (Subcategories: Community Development \& Philanthropy, Human Rights \& Supply Chain, Product)

- Employees (Subcategories: Compensation \& Benefits, Diversity \& Labor Rights, Training, Health \& Safety)

- Environment (Subcategories: Energy \& Climate Change, Environment Policy \& Reporting, Resource Management)

- Governance (Subcategories: Board, Leadership Ethics, Transparency \& Reporting)

It can be challenging to provide consistent and relevant CSR ratings/scores to a broad range of companies originated from different nations and industries due to the following reasons. First, different data sources track different topics in different ways. For example, one source might measure community dimension by total amount of money it contributes to local charities while another might track it by measuring the number of community activities involved by the company. Second, different sources use various ways to quantify the CSR performance, for example, the use of numerical score, positive or negative signs and relative rankings (such as "Top 100" or "Best Performing") are some of the common measures. Third, different countries apply different CSR reporting system and guidelines and it makes the CSR performance of different countries not comparable.

With the attempt to minimize the above sources of bias and inconsistency, CSRHub develops its rating system by using the following approach (CSRHub, 2017a):

- Map to a central schema: CSR performance is divided into four main categories (or dimensions) and twelve subcategories. An open-ended number of special issues is established to hold those CSR issues that do not fit into the twelve subcategory schema.

- Convert to a numeric scale: Each data item from different sources is converted into a positive rating on a 0 to 100 scale.

- Normalize: To analyze the variations between the sources, scores from different data sources for the same company are compared to determine the biases. The scores from a source are then adjusted to remove bias and create a more consistent rating.

- Aggregate: Each data source is weighted differently according to the estimate of its credibility and value. All the available data on a company is then incorporated to generate base ratings at the subcategory level and subsequently aggregated to generate the ratings for category or dimension level.

- Trim: Those companies that do not have sufficient CSR information will not be rated.

- Map to other international reporting standards: To generate a more reliable rating, CSRHub schema is mapped, for example, to the Global Reporting Initiative (GRI) G3.1 guideline. (CSRHub, 2017b)

To proxy for the CSR performance of GLCs, CSR ratings for 30 Malaysian GLCs were retrieved from CSRHub database. Average CSR ratings were then computed for each category (dimension), subcategory and industry (sector). 


\section{Results and findings}

Average CSR ratings of 30 GLCs listed on Bursa Malaysia for the year ending 2016 were computed based on 4 dimensions and 12 subcategories. The results are as illustrated in Table 1.

\section{Table 1}

Average CSR Ratings based on Dimensions and Subcategories

\begin{tabular}{|c|c|c|c|c|c|}
\hline $\begin{array}{l}\text { Ranking } \\
\text { of Dimen- } \\
\text { sion }\end{array}$ & $\begin{array}{l}\text { Dimensions/ } \\
\text { Subcategories }\end{array}$ & Average CSR Rating & Lowest & Highest & $\begin{array}{l}\text { Stand- } \\
\text { ard De- } \\
\text { viation }\end{array}$ \\
\hline \multirow[t]{4}{*}{1} & Environment & 64.67 & 53 & 92 & 9.57 \\
\hline & Energy \& Climate Change & 67.93 & 50 & 93 & 11.24 \\
\hline & Environment Policy \& Reporting & 64.03 & 51 & 95 & 8.35 \\
\hline & Resource Management & 61.87 & 41 & 91 & 11.88 \\
\hline \multirow[t]{4}{*}{2} & Employees & 61.40 & 41 & 79 & 8.28 \\
\hline & Diversity \& Labor Rights & 69.62 & 44 & 90 & 10.04 \\
\hline & Training, Health \& Safety & 64.21 & 48 & 75 & 6.76 \\
\hline & Compensation \& Benefits & 50.97 & 18 & 83 & 14.37 \\
\hline \multirow[t]{4}{*}{3} & Community & 61.10 & 47 & 87 & 9.33 \\
\hline & Community Development \& Philanthropy & 63.53 & 44 & 91 & 9.97 \\
\hline & Human Rights \& Supply Chain & 60.67 & 41 & 83 & 9.06 \\
\hline & Product & 53.05 & 37 & 66 & 7.76 \\
\hline \multirow[t]{4}{*}{4} & Governance & 55.37 & 36 & 84 & 9.81 \\
\hline & Leadership Ethics & 58.60 & 41 & 81 & 9.09 \\
\hline & Board & 54.73 & 32 & 87 & 11.74 \\
\hline & Transparency \& Reporting & 52.73 & 27 & 83 & 11.76 \\
\hline
\end{tabular}

The CSR dimension that GLCs performed the best in 2016 was Environment, followed by Employees and Community. The least favorable was Governance. Environment Dimension, with the highest average CSR rating, measures a company's interactions with the environment at large, including the efficiency in using natural resources, the impact of company's operation on the Earth's ecosystems, compliance with environmental regulations, etc. On average, GLCs scored 64.67 points on this dimension. Among the three subcategories, Energy and Climate Change received the highest average rating. This subcategory specifies the company's policies and strategies in addressing climate change, energy-efficient operations, development of renewable energy and other alternative environmental technologies. Employees Dimension includes the diversity of labor force, treatment of unions and labor rights, compensation and benefits of employees, occupational training, health and safety issues, etc. On average, GLCs scored 61.40 points on this dimension. Among the three subcategories, Diversity \& Labor Rights obtained the highest average rating. This subcategory evaluates a company's workplace policies and practices on fair and non-discriminatory treatments of employees and the ability to maintain diversity by providing equal opportunities on promotion and benefits regardless of regardless of age, gender, ethnicity, religion or sexual orientation, and promote work-life balance. Community Dimension covers the company's engagement in charitable giving and volunteerism, human rights and supply chain treatment, development of environmental-friendly and sustainable products, etc. On average, GLCs scored 61.10 points in this dimension. Among the three subcategories, Community Development \& Philanthropy obtained the highest average rating. This subcategory assesses how the company interacts with the communities in which it does business.

Governance Dimension has the lowest average rating (i.e. 55.37 points) as Malaysian public-listed GLCs tend to underperform on this dimension. This dimension includes board diversity, independence and compensation, leadership ethics of management, company's reporting practices and transparency to its stakeholders, etc. All three subcategories have a relatively low average rating. Out of twelve subcategories, GLCs performed the best in Diversity \& Labor Rights, Energy \& Climate Change and Training, Health \& Safety. However, they tend to underperform in Compensation \& Benefits, Transparency \& Reporting and Product. Subcategory of Compensation \& Benefits has the highest standard 
deviation (14.37 points) represents an evident dispersion of CSR ratings among the GLCs in this subcategory. Greater the value of standard deviation, larger the dispersion of CSR ratings. It is also confirmed by the largest difference between lowest and highest average CSR ratings, i.e. 18 and 83 respectively. Ranking of twelve subcategories of CSR are exhibited in Table 2.

Table 2

\begin{tabular}{cllcccc}
\multicolumn{2}{c}{ Ranking of Subcategories with Average CSR Rating } & & & \\
\hline Ranking & Subcategory & Dimension & $\begin{array}{c}\text { Lverage CSR } \\
\text { Rating }\end{array}$ & $\begin{array}{c}\text { High- } \\
\text { est }\end{array}$ & $\begin{array}{c}\text { Standard Devia- } \\
\text { est }\end{array}$ \\
\hline $\mathbf{1}$ & Diversity \& Labor Rights & Employees & 69.62 & 44 & 90 & 10.04 \\
$\mathbf{2}$ & Energy \& Climate Change & Environment & 67.93 & 50 & 93 & 11.24 \\
$\mathbf{3}$ & Training, Health \& Safety & Employees & 64.21 & 48 & 75 & 6.76 \\
$\mathbf{4}$ & Environment Policy \& Reporting & Environment & 64.03 & 51 & 95 & 8.35 \\
$\mathbf{5}$ & Community Development \& Philan- & Community & 63.53 & 44 & 91 & 9.97 \\
& thropy & Environment & 61.87 & 41 & 91 & 11.88 \\
$\mathbf{6}$ & Resource Management & Community & 60.67 & 41 & 83 & 9.06 \\
$\mathbf{7}$ & Human Rights \& Supply Chain & Governance & 58.6 & 41 & 81 & 9.09 \\
$\mathbf{8}$ & Leadership Ethics & Governance & 54.73 & 32 & 87 & 11.74 \\
$\mathbf{1 0}$ & Board & Community & 53.05 & 37 & 66 & 7.76 \\
$\mathbf{1 1}$ & Traduct & Governance & 52.73 & 27 & 83 & 11.76 \\
\hline
\end{tabular}

Descriptive statistics on the number of GLCs originated from different sectors, with an average CSR rating for each sector are as illustrated in Table 3.

Table 3

Average CSR Ratings based on Industries/Sectors

\begin{tabular}{lcccc}
\hline \multicolumn{1}{c}{ Industry/Sector } & No. of GLCs & Percentage on Total & Average CSR Rating & Standard Deviation \\
\hline Trading/Services & 14 & $46.67 \%$ & 59.70 & 5.10 \\
Finance & 5 & $16.67 \%$ & 59.66 & 7.99 \\
Properties & 3 & $10.00 \%$ & 58.96 & 11.49 \\
Consumer Products & 2 & $6.67 \%$ & 69.25 & 5.30 \\
Construction & 2 & $6.67 \%$ & 58.06 & 5.42 \\
Plantation & 1 & $3.33 \%$ & 52.19 & 5.47 \\
Industrial Products & 1 & $3.33 \%$ & 56.75 & 6.62 \\
IPC & 1 & $3.33 \%$ & 57.80 & 15.00 \\
REITs & 1 & $3.33 \%$ & 73.27 & 11.28 \\
\hline Total & 30 & $100.00 \%$ & & \\
\hline
\end{tabular}

Based on the average CSR ratings, the sectors with outstanding CSR performance include REITs and consumer products sectors, scoring an average CSR rating of 73.27 and 69.25 respectively. Plantation sector, however, has the lowest average CSR rating, i.e. poorer CSR performance compared to other sectors.

\section{Conclusion}

This paper has examined the CSR practice of 30 Malaysian public-listed GLCs in year 2016 by using CSR ratings obtained from CSRHub. The Environment dimension obtained the highest average CSR rating whilst Governance dimension the lowest. For subcategories, Diversity \& Labor Rights obtained the highest average CSR rating whilst Compensation \& Benefits the lowest. Both highest and lowest rated subcategories belong to Employees dimension. For sectors, REITs has the highest average CSR rating whilst Plantation the lowest. The results of present study were different from past literature, possibly due to the facts that past literature applied CSR disclosure score (i.e. self-reporting) to proxy for CSR, however, the present study adopted CSR rating (i.e. third-party assessment). CSR disclosure score is obtained through content analysis of company's annual reports, in contrary, CSR rating from 
CSRHub is derived from multiple sources of information. The findings of present study provide a valuable insight to GLCs to revise their CSR practice and to improve on the low-rating areas such as Product, Transparency \& Reporting and Compensation \& Benefits subcategories.

This study is subject to several limitations. First, only one year (i.e. year 2016) CSR performance has been studied. Second, small sample size of 30 GLCs makes the results of statistical tests inaccurate and insignificant as to study the differences in CSR practice across different industrial sectors. Third, unavailability of data on CSRHub makes large sample size study not feasible.

There are some suggestions for future study. First, a longitudinal study can be conducted to study the trends and patterns of CSR practice in Malaysian GLCs. Second, a comparative study of CSR practice between GLCs and non-GLCs may provide meaningful insights on their differences. Third, the study can be replicated by using a larger sample size to study the differences of CSR practice across different industrial sectors. Fourth, regression tests can be done to examine the relationship between CSR ratings and other corporate attributes such as firm's size, firm's profitability, etc. Fifth, interview or question-

naire survey can be conducted to investigate the underlying reasons and motives of contributing more in certain CSR dimensions and subcategories.

\section{References}

Ahmad, N. N. N., Sulaiman, M., \& Siswantoro, D. (2003). Corporate social responsibility disclosure in Malaysia: An analysis of annual reports of KLSE listed companies. International Journal of Economics, Management and Accounting, 11(1).

Alamer, A. R. A., Salamon, H. B., Qureshi, M. I., \& Rasli, A. M. (2015a). CSR's measuring corporate social responsibility practice in Islamic banking: A review. International Journal of Economics and Financial Issues, 5(1S).

Alamer, A. R. A., Salamon, H. B., Qureshi, M. I., \& Rasli, A. M. (2015). How do We Measure Corporate Social Responsibility of Islamic Banks through their Business Processes and Oriented Outcomes? International Journal of Economics and Financial Issues, 5.

Alamer, A. R. A., Salamon, H. B., Qureshi, M. I., \& Rasli, A. M. (2015b). A New Business Process and Outcome Oriented Corporate Social Responsibility Index for Islamic Banking. International Journal of Economics and Financial Issues, 5.

Andrew, B. H., Gul, F. A., Guthrie, J. E., \& Teoh, H. Y. (1989). A note on corporate social disclosure practices in developing countries: the case of Malaysia and Singapore. The British Accounting Review, 21(4), 371-376.

Alamer, A. R. A., Salamon, H. B., Qureshi, M. I., \& Rasli, A. M. (2015a). CSR's measuring corporate social responsibility practice in Islamic banking: A review. International Journal of Economics and Financial Issues, 5(1S).

Alamer, A. R. A., Salamon, H. B., Qureshi, M. I., \& Rasli, A. M. (2015). How do We Measure Corporate Social Responsibility of Islamic Banks through their Business Processes and Oriented Outcomes? International Journal of Economics and Financial Issues, 5.

Alamer, A. R. A., Salamon, H. B., Qureshi, M. I., \& Rasli, A. M. (2015b). A New Business Process and Outcome Oriented Corporate Social Responsibility Index for Islamic Banking. International Journal of Economics and Financial Issues, 5.

Atan, R., \& Razali, N. M. (2013). CSR reporting by government linked companies and their corporate attributes. Australian Journal of Basic and Applied Sciences, 7(4), 163-171.

Bhatt, P. R. (2016). Performance of government linked companies and private owned companies in Malaysia. International Journal of Law and Management, 58(2), 150-161.

CSRHub (2017a). The CSRHub Ratings Methodology. Retrieved on April 24, 2017, from https://www.csrhub.com/content/csrhub-ratings-methodology/ 
CSRHub (2017b). GRI G3 Mapped to CSRHub Schema. Retrieved on April 24, 2017, from https://www.csrhub.com/content/gri-g3-mapped-csrhub-schema/

Gandhi, S., Sachdeva, A \& Gupta, A. (2018). Distributor service quality in Indian SMEs: A bi-directional customer perspective. Uncertain Supply Chain Management, 6(4), 335-356.

Hawani Wan Abd Rahman, N., Mohamed Zain, M., \& Hanim Yaakop Yahaya Al-Haj, N. (2011). CSR disclosures and its determinants: evidence from Malaysian government link companies. Social Responsibility Journal, 7(2), 181-201.

Mariati, N. and A.A. Kamarulzaman. (2005). Smart Partnership or Cronysm? A Malaysian Perspective. The International Journal of Sociology and Social Policy, 25(8): 31-48.

Putrajaya Committee on GLC High Performance Transformation (2013). GLC Transformation Programme Progress Review Report, Putrajaya.

Ramakrishnan, S., Hishan, S. S., Shahabuddin, A. S. M., \& Kanjanapathy, M. (2016). The Role of Corporate Social Responsibility in Flood Mitigation among the Listed Insurance Companies in Malaysia. International Review of Management and Marketing, 6(4S).

Shirley, C., Suan, A. G., Leng, C. P., Okoth, M. O., Fei, N. B., \& PJU, K. D. (2009). Corporate social responsibility reporting in Malaysia: An analysis of Website reporting of Second Board companies listed in Bursa Malaysia. SEG Review, 2(2), 85-98.

Siwar, C., \& Harizan, S. H. M. (2009). A study on corporate social responsibility practices amongst business organizations in Malaysia. In Proceedings of the tenth international business research conference, Dubai, United Arab Emirates.

Teoh, H. Y., \& Thong, G. (1984). Another look at corporate social responsibility and reporting: an empirical study in a developing country. Accounting, Organizations and Society, 9(2), 189-206.

\section{Appendix}

List of Public-Listed GLCs

\begin{tabular}{|c|c|}
\hline Name of GLCs & Sector \\
\hline 1. Affin Holdings Bhd & Finance \\
\hline 2. Axiata Group Bhd & Trad/Serv \\
\hline 3. BIMB Holdings Bhd & Finance \\
\hline 4. Boustead Holdings Bhd & Trad/Serv \\
\hline 5. Bursa Malaysia Berhad & Finance \\
\hline 6. Dutch Lady Milk Industries Bhd & Consumer \\
\hline 7. Felda Global Ventures Holdings Bhd & Plantation \\
\hline 8. Gamuda Bhd & Constructn \\
\hline 9. IHH Healthcare Berhad & Trad/Serv \\
\hline 10. IJM Corporation Bhd. & Constructn \\
\hline 11. KLCC Property Holdings Bhd & REITS \\
\hline 12. KPJ Healthcare Berhad & Trad/Serv \\
\hline 13. Malakoff Corporation Berhad & Trad/Serv \\
\hline 14. Malayan Banking Bhd & Finance \\
\hline 15. Malaysia Airports Holdings Bhd & Trad/Serv \\
\hline 16. Malaysia Building Society Berhad & Finance \\
\hline 17. Malaysian Resources Corporation Berhad & Properties \\
\hline 18. MISC Berhad & Trad/Serv \\
\hline 19. MMC Corporation Berhad & Trad/Serv \\
\hline 20. Petronas Dagangan Bhd & Trad/Serv \\
\hline 21. Petronas Gas Bhd & Ind-Prod \\
\hline 22. Pos Malaysia Berhad & Trad/Serv \\
\hline 23. Sime Darby Bhd & Trad/Serv \\
\hline 24. S P Setia Bhd & Properties \\
\hline 25. Telekom Malaysia Bhd & Trad/Serv \\
\hline 26. Tenaga Nasional Bhd & Trad/Serv \\
\hline 27. Time Dotcom Bhd & IPC \\
\hline 28. UMW Holdings Bhd & Consumer \\
\hline 29. UOA Development Bhd & Properties \\
\hline 30. Westports Holdings Bhd & Trad/Serv \\
\hline
\end{tabular}




\begin{tabular}{|c|c|c|c|}
\hline COMMUNITY & $\begin{array}{l}\text { Community Development and Phi- } \\
\text { lanthropy }\end{array}$ & $\begin{array}{c}\text { Community Subcategories } \\
\text { Human Rights and Supply Chain }\end{array}$ & Product \\
\hline $\begin{array}{l}\text { The Community Category covers the } \\
\text { company's commitment and effective- } \\
\text { ness within the local, national and } \\
\text { global community in which it does } \\
\text { business. It reflects a company's citi- } \\
\text { zenship, charitable giving, and volun- } \\
\text { teerism. This category covers the com- } \\
\text { pany's human rights record and treat- } \\
\text { ment of its supply chain. It also covers } \\
\text { the environmental and social impacts of } \\
\text { the company's products and services, } \\
\text { and the development of sustainable } \\
\text { products, processes and technologies. }\end{array}$ & $\begin{array}{l}\text { The Community Development and Phi- } \\
\text { lanthropy subcategory covers the rela- } \\
\text { tionship between a company and the } \\
\text { communities within which it is embed- } \\
\text { ded. It reflects a company's community } \\
\text { citizenship through charitable giving, } \\
\text { donations of goods, and volunteerism } \\
\text { of staff time. It also includes protecting } \\
\text { public health (e.g., avoidance of indus- } \\
\text { trial accidents) and managing the social } \\
\text { impacts of its operations on local com- } \\
\text { munities. The subcategory also in- } \\
\text { cludes a company's land use and build- } \\
\text { ing design impact on the local economy } \\
\text { and ecosystem. }\end{array}$ & $\begin{array}{l}\text { The Human Rights and Supply Chain } \\
\text { subcategory measures a company's } \\
\text { commitment to respecting fundamental } \\
\text { human rights conventions, its ability to } \\
\text { maintain its license to operate by sup- } \\
\text { porting freedom of association and ex- } \\
\text { cluding child, forced or compulsory la- } \\
\text { bor. This subcategory covers a com- } \\
\text { pany's transparency in overseas sourc- } \\
\text { ing disclosure and monitoring and a } \\
\text { company's relationship with and re- } \\
\text { spect for the human rights of indige- } \\
\text { nous peoples near its proposed or cur- } \\
\text { rent operations. }\end{array}$ & $\begin{array}{l}\text { The Product subcategory covers the re- } \\
\text { sponsibility of a company for the de- } \\
\text { velopment, design, and management of } \\
\text { its products and services and their im- } \\
\text { pacts on customers and society at large. } \\
\text { This subcategory reflects a company's } \\
\text { capacity to reduce environmental costs, } \\
\text { create new market opportunities } \\
\text { through new sustainable technologies } \\
\text { or processes, and produce or market } \\
\text { goods and services that enhance the } \\
\text { health and quality of life for consum- } \\
\text { ers. This subcategory rating covers the } \\
\text { integrity of a company's products and } \\
\text { sales practices, including their labeling } \\
\text { and marketing, social impacts and end- } \\
\text { of-life disposition. It also relates to } \\
\text { product safety and quality and the com- } \\
\text { pany's response to problems with } \\
\text { safety and quality. }\end{array}$ \\
\hline \multirow{2}{*}{ EMPLOYEES } & \multicolumn{3}{|c|}{ Employees Subcategory } \\
\hline & Compensation and Benefits & Diversity and Labor Rights & Training, Safety and Health \\
\hline $\begin{array}{l}\text { The Employees category includes dis- } \\
\text { closure of policies, programs, and per- } \\
\text { formance in diversity, labor relations } \\
\text { and labor rights, compensation, bene- } \\
\text { fits, and employee training, health and } \\
\text { safety. The evaluation focuses on the } \\
\text { quality of policies and programs, com- } \\
\text { pliance with national laws and regula- } \\
\text { tions, and proactive management initia- } \\
\text { tives. The category includes evaluation } \\
\text { of inclusive diversity policies, fair } \\
\text { treatment of all employees, robust di- } \\
\text { versity (EEO-1) programs and training, } \\
\text { disclosure of workforce diversity data, } \\
\text { strong labor codes (addressing the core } \\
\text { ILO standards), comprehensive bene- } \\
\text { fits, demonstrated training and develop- } \\
\text { ment opportunities, employee health } \\
\text { and safety policies, basic and industry- } \\
\text { specific safety training, demonstrated } \\
\text { safety management systems, and a pos- } \\
\text { itive safety performance record. }\end{array}$ & $\begin{array}{l}\text { The Compensation and Benefits sub- } \\
\text { category covers a company's capacity } \\
\text { to increase its workforce loyalty and } \\
\text { productivity through rewarding, fair, } \\
\text { and equal compensation and financial } \\
\text { benefits. It includes benefits that en- } \\
\text { gage employees and improve worker } \\
\text { development. This subcategory also fo- } \\
\text { cuses on long-term employment growth } \\
\text { and stability by promotion practices, } \\
\text { lay-off practices, and relations with re- } \\
\text { tired employees. }\end{array}$ & $\begin{array}{l}\text { The Diversity and Labor Rights subcat- } \\
\text { egory covers workplace policies and } \\
\text { practices covering fair and non-dis- } \\
\text { criminatory treatment of employees, } \\
\text { and its diversity policies. It covers a } \\
\text { company's labor-management relations } \\
\text { and participation by employees, Na- } \\
\text { tional Labor Relations Board (NLRB) } \\
\text { violations or patterns of anti-union } \\
\text { practice, conformance to internation- } \\
\text { ally recognized worker rights, as de- } \\
\text { fined in the basic conventions of the In- } \\
\text { ternational Labor Organization (ILO). } \\
\text { Fundamental labor rights include free- } \\
\text { dom of association and protection of } \\
\text { the right to organize; right to bargain } \\
\text { collectively; a minimum age for the } \\
\text { employment of children; a prohibition } \\
\text { against forced labor; lack of employ- } \\
\text { ment and occupational discrimination; } \\
\text { and equal compensation. This subcate- } \\
\text { gory measures a company's ability to } \\
\text { maintain diversity, provide equal op- } \\
\text { portunities regardless of gender, age, } \\
\text { ethnicity, religion or sexual orientation, } \\
\text { and promote work-life balance. }\end{array}$ & $\begin{array}{l}\text { The Training, Safety and Health sub- } \\
\text { category measures a company's effec- } \\
\text { tiveness in providing a healthy and safe } \\
\text { workplace. This subcategory includes } \\
\text { accident and safety performance, as } \\
\text { well as job training, safety standards } \\
\text { and training, and employee-manage- } \\
\text { ment safety teams. It includes programs } \\
\text { to support the health, well-being and } \\
\text { productivity of all employees. This } \\
\text { subcategory includes workplace poli- } \\
\text { cies and programs that boost employee } \\
\text { morale, workplace productivity, com- } \\
\text { pany policies and practices to engage } \\
\text { employees, and worker development. }\end{array}$ \\
\hline ENVIRONMENT & Energy and Climate Change & $\begin{array}{c}\text { Environment Subcategory } \\
\text { Environmental Policy and Reporting }\end{array}$ & Resource Management \\
\hline $\begin{array}{l}\text { The Environment category data covers } \\
\text { a company's interactions with the envi- } \\
\text { ronment at large, including use of natu- } \\
\text { ral resources, and a company's impact } \\
\text { on the Earth's ecosystems. The cate- } \\
\text { gory evaluates corporate environmental } \\
\text { performance, compliance with environ- } \\
\text { mental regulations, mitigation of envi- } \\
\text { ronmental footprint, leadership in ad- } \\
\text { dressing climate change through appro- } \\
\text { priate policies and strategies, energy- } \\
\text { efficient operations, and the develop- } \\
\text { ment of renewable energy and other al- } \\
\text { ternative environmental technologies, } \\
\text { disclosure of sources of environmental } \\
\text { risk and liability and actions to mini- } \\
\text { mize exposure to future risk, imple- } \\
\text { mentation of natural resource conserva- } \\
\text { tion and efficiency programs, pollution } \\
\text { prevention programs, demonstration of } \\
\text { a strategy toward sustainable develop- } \\
\text { ment, integration of environmental sus- } \\
\text { tainability and responsiveness with } \\
\text { management and the board, and pro- } \\
\text { grams to measure and engage stake- } \\
\text { holders for environmental improve- } \\
\text { ment. }\end{array}$ & $\begin{array}{l}\text { The Energy and Climate Change sub- } \\
\text { category measures a company's effec- } \\
\text { tiveness in addressing climate change } \\
\text { through appropriate policies and strate- } \\
\text { gies, energy-efficient operations, and } \\
\text { the development of renewable energy } \\
\text { and other alternative environmental } \\
\text { technologies. The subcategory includes } \\
\text { energy use, emissions to air of CO2 } \\
\text { and other Greenhouse Gas Emissions } \\
\text { (GHG). }\end{array}$ & $\begin{array}{l}\text { The Environmental Policy and Report- } \\
\text { ing subcategory includes a company's } \\
\text { policies and intention to reduce the en- } \\
\text { vironmental impact of a company and } \\
\text { its value stream to levels that are } \\
\text { healthy for the company and for the en- } \\
\text { vironment, now and in the future. The } \\
\text { data includes the company's environ- } \\
\text { mental reporting performance, adher- } \\
\text { ence to environmental reporting stand- } \\
\text { ards such as the Global Reporting Initi- } \\
\text { ative, and compliance with investor, } \\
\text { regulatory and stakeholders' requests } \\
\text { for transparency. Compliance data con- } \\
\text { sists of breaches of regulatory limits } \\
\text { and accidental releases. }\end{array}$ & $\begin{array}{l}\text { The Resource Management subcate- } \\
\text { gory covers how efficiently resources } \\
\text { are used in manufacturing and deliver- } \\
\text { ing products and services, including } \\
\text { those of a company's suppliers. It in- } \\
\text { cludes a company's capacity to reduce } \\
\text { the use of materials, energy or water, } \\
\text { and to find more efficient solutions by } \\
\text { improving its supply chain manage- } \\
\text { ment. This subcategory includes envi- } \\
\text { ronmental performance relative to pro- } \\
\text { duction size and is monitored by the } \\
\text { production-related Eco Intensity Ratios } \\
\text { (EIRs) for water and energy defined as } \\
\text { resource consumption per produced or } \\
\text { released unit. Resource materials in- } \\
\text { clude raw materials and packaging ma- } \\
\text { terials for production and related pro- } \\
\text { cesses and packaging of products. Re- } \\
\text { source Management data also include } \\
\text { waste and recycling performance. Re- } \\
\text { cycling data is related to the proportion } \\
\text { of waste recycled of the total waste. } \\
\text { Data includes how the company man- } \\
\text { ages operations to benefit the local } \\
\text { airshed and watershed, and how the } \\
\text { company impacts land use and local } \\
\text { ecological stability. The water resource } \\
\text { data includes consumption of drinking } \\
\text { water, industrial water and steam. }\end{array}$ \\
\hline
\end{tabular}




\begin{tabular}{|c|c|c|c|}
\hline \multirow{2}{*}{ GOVERNANCE } & \multicolumn{3}{|c|}{ Governance Subcategory } \\
\hline & Board & Leadership Ethics & Transparency and Reporting \\
\hline $\begin{array}{l}\text { The Governance category covers dis- } \\
\text { closure of policies and procedures, } \\
\text { board independence and diversity, ex- } \\
\text { ecutive compensation, attention to } \\
\text { stakeholder concerns, and evaluation of } \\
\text { a company's culture of ethical leader- } \\
\text { ship and compliance. Corporate gov- } \\
\text { ernance refers to leadership structure } \\
\text { and the values that determine corporate } \\
\text { direction, ethics and performance. This } \\
\text { category rates factors such as: are cor- } \\
\text { porate policies and practices aligned } \\
\text { with sustainability goals; is the man- } \\
\text { agement of the corporation transparent } \\
\text { to stakeholders; are employees appro- } \\
\text { priately engaged in the management of } \\
\text { the company; are sustainability princi- } \\
\text { ples integrated from the top down into } \\
\text { the day-to-day operations of the com- } \\
\text { pany. Governance focuses on how } \\
\text { management is committed to sustaina- } \\
\text { bility and corporate responsibility at all } \\
\text { levels. }\end{array}$ & $\begin{array}{l}\text { The Board subcategory covers a com- } \\
\text { pany's effectiveness in following best } \\
\text { practices in corporate governance prin- } \\
\text { ciples related to board membership, in- } \\
\text { dependent decision making through ex- } \\
\text { perienced, diverse and independent } \\
\text { board members, effectiveness toward } \\
\text { following best practices related to } \\
\text { board activities and functions, and } \\
\text { board committee structure and compo- } \\
\text { sition. It includes how the company } \\
\text { provides competitive and proportionate } \\
\text { management compensation and its abil- } \\
\text { ity to incent executives and board } \\
\text { members to achieve both financial and } \\
\text { extra-financial targets. }\end{array}$ & $\begin{array}{l}\text { The Leadership Ethics subcategory } \\
\text { measures how a company manages its } \\
\text { relationships with its various stakehold- } \\
\text { ers, including investors, customers, } \\
\text { communities, and regulators. This sub- } \\
\text { category measures a company's effec- } \\
\text { tiveness in treating its shareholders eq- } \\
\text { uitably. Leadership ethics includes the } \\
\text { company's culture of ethical decision } \\
\text { making. It measures a company's com- } \\
\text { mitment and effectiveness toward the } \\
\text { vision of integrating social and envi- } \\
\text { ronmental aspects into the overall core } \\
\text { strategy and whether sustainability } \\
\text { principles are integrated from the top } \\
\text { down into the day-to-day operations of } \\
\text { the company. }\end{array}$ & $\begin{array}{l}\text { The Transparency and Reporting sub- } \\
\text { category rates factors including are cor- } \\
\text { porate policies and practices aligned } \\
\text { with sustainability goals, is the man- } \\
\text { agement of the corporation transparent } \\
\text { to stakeholders, are employees appro- } \\
\text { priately engaged in the management of } \\
\text { the company, and do sustainability re- } \\
\text { ports comply with standards such as the } \\
\text { Global Reporting Initiative, AccountA- } \\
\text { bility (AA1000) and other standards, } \\
\text { and are these reports made publicly } \\
\text { available. This subcategory includes } \\
\text { whether the company provides a list of } \\
\text { its major stakeholders and how it en- } \\
\text { gages with them. It also covers whether } \\
\text { the company is a signatory of Global } \\
\text { Compact and other leading global enti- } \\
\text { ties. It evaluates the assurance (3rd } \\
\text { party audit) of the accuracy, complete- } \\
\text { ness, and reliability of its Sustainability } \\
\text { or Corporate Social Responsibility re- } \\
\text { ports. }\end{array}$ \\
\hline
\end{tabular}

Source: https://www.csrhub.com/content/csrhub-data-schema/

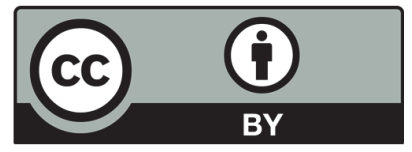

(C) 2018 by the authors; licensee Growing Science, Canada. This is an open access article distributed under the terms and conditions of the Creative Commons Attribution (CC-BY) license (http://creativecommons.org/licenses/by/4.0/). 